\title{
New India Rehabilitation and Resettlement Policy, and Associated Legislative Measures Relating to Land Acquisition
}

$\mathbf{T}$ he Union Cabinet gave its approval for the National Policy on Rehabilitation and Resettlement, 2007, to replace the National Policy on Resettlement and Rehabilitation for Project Affected Families, 2003. A Gazette Notification will be issued shortly to bring into effect the new Policy.

The Cabinet also decided to bring legislation on the lines of the new Rehabilitation and Resettlement (RR) Policy, and to suitably amend the Land Acquisition Act, 1894. Necessary steps shall be taken in this regard as per the established procedure.

The new Policy and the associated legislative measures aim at striking a balance between the need for land for developmental activities and, at the same time, protecting the interests of the land owners, and others, such as the tenants, the landless, the agricultural and non-agricultural labourers, artisans, and others whose livelihood depends on the land involved. The benefits under the new Policy shall be available to all affected persons and families whose land, property or livelihood is adversely affected by land acquisition or by involuntary displacement of a permanent nature due to any other reasons, such as natural calamities, etc. The Policy will be applicable to all these cases irrespective of the number of people involved.

The benefits to be offered under the new Policy to the affected families include; land-for-land, to the extent Government land would be available in the resettlement areas; preference for employment in the project to at least one person from each nuclear family within the definition of the 'affected family', subject to the availability of vacancies and suitability of the affected person; training and capacity building for taking up suitable jobs and for self-employment; scholarships for education of the eligible persons from the affected families; preference to groups of cooperatives of the affected persons in the allotment of contracts and other economic opportunities in or around the project site; wage employment to the willing affected persons in the construction work in the project; housing benefits including houses to the landless affected families in both rural and urban areas; and other benefits.

Adequate provisions have also been made for financial support to the affected families for the construction of cattle sheds, shops, and working sheds; transportation costs, temporary and transitional accommodation, and comprehensive infrastructural facilities and amenities in the resettlement area including education, health care, drinking water, roads, electricity, sanitation, religious activities, cattle grazing, and other community resources, etc.
The benefits expressed in monetary terms have been linked to the Consumer Price Index, and the same shall also be revised suitably at appropriate intervals.

The Requiring Bodies shall be responsible for development of designated areas on the periphery of the project site, and shall earmark funds for the purpose of such periphery development activities.

A special provision has been made for providing life-time monthly pension to the vulnerable persons, such as the disabled, destitute, orphans, widows, unmarried girls, abandoned women, or persons above 50 years of age (who are not provided or cannot immediately be provided with alternative livelihood).

Special provision for the Scheduled Tribes (STs) and Scheduled Castes (SCs) include preference in landfor-land for STs followed by SCs; a Trial Development Plan which will also include a programme for development for alternate fuel and non-timber forest produce resources, consultations with Gram Sabhas and Tribal Advisory Councils, protection of fishing rights, land free-of-cost for community and religious gatherings, continuation of reservation benefits in resettlement areas, etc.

A strong grievance redressal mechanism has been prescribed, which includes standing R\&R Committees at the district level, R\&R Committees at the project level, and an Ombudsman duly empowered in this regard. The R\&R Committees shall have representatives from the affected families including women, voluntary organisations, Panchayats, local elected representatives, etc.

Provision has also been made for postimplementation social audits of the rehabilitation and resettlement schemes and plans.

For effective monitoring of the progress of implementation of R\&R plans, provisions have been made for a National Monitoring Committee, a National Monitoring Cell, mandatory information sharing by the States and Union Territories (UTs) with the National Monitoring Cell, and Oversight Committees in the Ministries/Departments concerned for each major project, etc.

For ensuring transparency, provision has been made for mandatory dissemination of information on displacement, rehabilitation and resettlement, with names of the affected persons and details of the rehabilitation packages. Such information shall be placed in the public domain on the Internet as well as shared with the concerned Gram Sabhas and Panchayats, etc. by the project authorities.

A National Rehabilitation Commission shall be set up by the Central Government, which will be duly empowered to exercise independent oversight over the rehabilitation and resettlement of the affected 
families.

Under the new Policy, no project involving displacement of families beyond defined thresholds can be undertaken without a detailed Social Impact Assessment (SIA), which among other things, shall also take into account the impact that the project will have on public and community properties, assets and infrastructure; and the concerned Government shall have to specify that the ameliorative measures for addressing the said impact, may not be less than what is provided under any scheme or programme of the Central or State Government in operation in the area. The SIA report shall be examined by an independent multi-disciplinary expert group, which will also include social science and rehabilitation experts. Following the conditions of the SIA clearance shall be mandatory for all projects displacing people beyond the defined thresholds.

The affected communities shall be duly informed and consulted at each stage, including public hearings in the affected areas for Social Impact Assessment, wide dissemination of the details of the survey to be conducted for R\&R plan or scheme, consultations with the Gram Sabhas and public hearings in areas not having Gram Sabhas, consultations with the affected families including women, NGOs, Panchayats, and local elected representatives, among others.

Consultations with the Gram Sabhas in the Scheduled Areas shall be held as per the provisions of the PESA Act, 1996.

The Policy also provides that land acquired for a public purpose cannot be transferred to any other purpose but a public purpose, and that too, only with prior approval of the Government. If land acquired for a public purpose remains un-utilized for the purpose for five years from the date of taking over the possession, the same shall revert to the Government concerned. When land acquired is transferred for a consideration, eighty per cent of any net unearned income so accruing to the transferor, shall be shared with the persons from whom the lands were acquired, or their heirs, in proportion to the value of the lands acquired.

The entitled persons shall have the option to take up to twenty per cent of their rehabilitation grant and compensation amount in the form of shares, if the Requiring Body is a company authorized to issue shares and debentures; with prior approval of the Government, this proportion can be as high as fifty per cent of the rehabilitation grant and compensation amount.

One of the objectives of the Policy is to minimize displacement of people and to promote non-displacing or least-displacing alternatives. The Policy also recommends that only the minimum necessary area of land commensurate with the purpose of the project should be taken, and the use of agricultural land for non-agricultural purposes should be kept to the minimum; multi-crop land should be avoided and irrigated land use should be kept to the minimum for such purposes. Projects may preferably be set up on wastelands or un-irrigated lands.

The Policy has been formulated after wide-ranging consultations with the concerned Ministries/ Departments, the States and the Union Territories, the industry groups, persons/groups actively engaged in the field of R\&R, and the public at large.

Shekhar Singh, New Delhi, India, (Source: www.displacement.net) 